\title{
Lannoitetypen huuhtoutumisen kinetiikasta ja määristä ruokohelvellä ja nurmella
}

\author{
Simo Jokinen ${ }^{1}$, Christina Biasi ${ }^{1}$, Hannu Nykänen ${ }^{2}$, Mari Räty $^{3}$, Perttu Virkajärvi ${ }^{3}$, Pertti Martikainen ${ }^{1}$
}

\author{
${ }^{1}$ Itä-Suomen Yliopisto, Ympäristötieteen laitos, PL 1627, 70211 Kuopio, simo.jokinen@uef.fi / \\ simo.jokinen@mtt.fi \\ Itä-Suomen Yliopisto, Ympäristötieteen laitos, PL 1627, 70211 Kuopio, christina.biasi@ uef.fi \\ ${ }^{2}$ Jyväskylän Yliopisto, Bio- ja ympäristötieteiden laitos, PL 35, 40014 Jyväskylä, \\ hannu.k.nykanen@jyu.fi

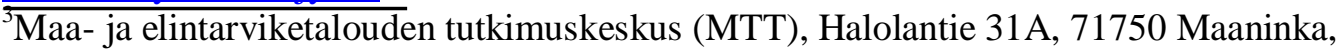 \\ mari.raty@mtt.fi

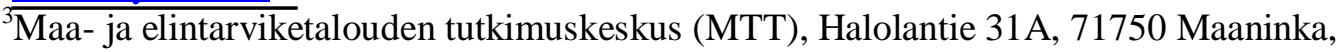 \\ perttu.virkajarvi@mtt.fi
}

IItä-Suomen Yliopisto, Ympäristötieteen laitos, PL 1627, 70211 Kuopio, pertti.martikainen@uef.fi

\section{Tiivistelmä}

Maatalous aiheuttaa noin $50 \%$ Suomen vesistöjen typpikuormituksesta. Huuhtoumaan vaikuttaa mm. kasvilaji. Monivuotisten energiakasvien typpihuuhtoumia ei tunneta hyvin. Tässä työssä verrattiin Ruokohelven (Phalaris arundinaceae) ja nurmen typen huuhtoumia kivennäismaalla. Nurmiviljelyn tiedetään vähentävän typpihuuhtoumaa. Ruokohelpi on bioenergiakasvina osoittautunut tehokkaaksi hiilinieluksi eloperäisillä mailla, ja sen dityppioksidipäästöt eloperäisiltä mailta ovat olleet alhaiset. Tutkimuksessa sovellettiin isotooppitekniikoita antamalla typpilannoitus typpi-15 rikastetulla (10 AT-\%) ammoniumnitraattina $\left({ }^{15} \mathrm{NH}_{4}{ }^{15} \mathrm{NO}_{3}\right)$. Työssä määritettiin mikä on lannoitetypen huuhtouman osuus kokonaistyppihuuhtoumasta..

Ruokohelpi- ja nurmikoealat lannoitettiin noudattaen kasvikohtaisia käytäntöjä (ruokohelpi 80 $\mathrm{kg} \mathrm{N} \mathrm{ha}^{-1}$, nurmi $2 *$ kertaan $100 \mathrm{~kg} \mathrm{~N} \mathrm{ha}^{-1}$ ). Vesinäytteet kerättiin typpianalyyseihin maaperään $0,8 \mathrm{~m}$ syvyyteen esiasennetuista keraamisista imuputkista. Näytteistä määritettiin mineraalitypen $\left(\mathrm{NH}_{4} \mathrm{ja}\right.$ $\mathrm{NO}_{3}$ ) pitoisuudet sekä niiden typpi-isotooppikoostumukset. Näytteenottomenetelmä ei sallinut huuhtouman määrällistä arviointia, vaan enemmänkin laadullisen $(15 \mathrm{~N} / 14 \mathrm{~N})$. Tutkimus toteutettiin Maaningalla kesäkuusta 2011 kesäkuuhun 2012 koealoilla, jotka oli perustettu keväällä 2009.

Kummallakin kasvilla nitraattityppipitoisuudet $0,8 \mathrm{~m}$ syvyydellä olivat keskimäärin $7 \mathrm{mg} \mathrm{NO} 3^{-}$ $\mathrm{N}^{-1}$ heinäkuun loppuun asti, jonka jälkeen $\mathrm{NO}_{3}-\mathrm{N}$-pitoisuudet lähtivät laskuun, ruokohelvellä nopeammin. Lokakuun 2011 lopussa ruokohelpiviljelmän $\mathrm{NO}_{3}-\mathrm{N}$ pitoisuus jäi alle $1 \mathrm{mg} \mathrm{l}^{-1}$ kun se nurmella oli 3,5 $\mathrm{mg} \mathrm{l}^{-1}$.

Ensimmäisen lannoituksen jälkeen lannoitetypen prosentuaalinen osuus $0,8 \mathrm{~m}$ syvyyden nitraattitypestä oli kummallakin kasvilla alle $1 \%$. Ruokohelvellä lannoiteperäinen huuhtouma ei juuri muuttunut kasvukauden edetessä. Nurmelle annettu toinen lannoitus nosti lannoiteperäisen typen huuhtouman 34,5 $\pm 19,2$ \%:iin. Suuri huuhtouma liittyi todennäköisesti toisen lannoituksen jälkeen tulleeseen rankkasateeseen, mikä huuhtoi pintamaahan kertynyttä lannoitetyppeä syvemmälle maaprofiiliin. Kohonnutta lannoitetypen huuhtoumaa ei kuitenkaan seurannut kohonnut $\mathrm{NO}_{3}-\mathrm{N}$ kokonaispitoisuus.

Nurmelta huuhtoutuvan nitraattitypen kokonaispitoisuus ei poikennut merkittävästi ruokohelven vastaavasta, vaikka nurmea lannoitettiin enemmän. Sen sijaan toista lannoitusta seurannut lannoitetypen huuhtouma nurmelta oli huomattavan korkea.

Asiasanat: ruokohelpi, nurmi, typpihuuhtouma, typpi-15 


\section{Johdanto}

Maatalous aiheuttaa Suomessa noin $50 \%$ vesistöihin kohdistuvasta typpihuuhtoumasta (Valpasvuo-Jaatinen ym., 1997). Huuhtoumaan vaikuttavat $\mathrm{mm}$. kasvilaji ja sen vaatima viljelykäytäntö sekä vallitsevat sääolot. Pohjois-Savo on voimakasta nautakarjatalousaluetta ja nurmenviljely kattaa noin $50 \%$ peltopinta-alasta (TIKE, 2012). Tavanomaisten nurmikasvien typen hyväksikäyttö on nurmivuosina tehokasta. Koska nurmi pystyy hyödyntämään voimakkaankin typpilannoituksen, huuhtoumat ovat useimmiten vähäisiä (Salo ym., 2013). Sen sijaan monivuotisten energiakasvien typpihuuhtoumia ei tunneta hyvin ja suurin osa tiedoista on peräisin eloperäisiltä mailta (mm. Partala \& Turtola, 2000). Tässä työssä verrattiin bioenergiaksi tuotetun ruokohelven (Phalaris arundinaceae L.) ja tyypillisen säilörehunurmen typen huuhtoumia kivennäismaalla. Ruokohelpi on bioenergiakasvina osoittautunut tehokkaaksi hiilinieluksi eloperäisillä mailla (Shurpali ym., 2009), ja sen dityppioksidipäästöt eloperäisiltä mailta ovat olleet alhaiset (Hyvönen ym., 2009), mikä liittynee tämän kasvin tehokkaaseen typen hyödyntämiseen. Yksi syy mataliin päästöihin eloperäisillä mailla on se, että keväisin korjattavalle ruokohelvelle annettava typpilannoitusmäärä on huomattavasti alhaisempi kuin säilörehutuotannossa.

Typpilannoituksen määrän lisäksi typen huuhtoutumiseen ja sen dynamiikkaan vaikuttavat myös muut viljely- ja säätekijät, kuten lannoituksen ajoitus ja kerta-annoksien suuruus sekä voimakkaiden sateiden ajoittuminen pian lannoituksen jälkeen (Whitehead, 1995). Myös sadonkorjuu heikentää hetkellisesti kasvien kykyä käyttää lannoitetyppeä (Richards, 1993). Lannoitetypen oton ja huuhtoutumisen dynamiikan parempi tuntemus auttaisi kehittämään entistä parempia viljelykäytäntöjä ja vertailemaan erilaisten tuotantomuotojen vaikutusta typen huuhtoutumiseen.

Typpihuuhtouman dynamiikkaa selvittävä tutkimus on osa laajempaa kokonaisuutta, jossa vertaillaan kevätkorjattavan ruokohelven sekä kahdesti kesässä korjattavan säilörehunurmen maaperäja ilmastovaikutuksia kivennäismaalla. Kummankin viljelykasvin tuotannossa noudatettiin tyypillisiä kasvikohtaisia viljelykäytäntöjä (Mavi, 2013). Tämän tutkimuksen tarkoituksena oli seurata lannoitetypen (ammonium ja nitraatti) liikkumista maaprofiilissa eri syvyyksiin asennettujen vesikeräinten avulla. Tässä raportissa käsitellään vain $0,8 \mathrm{~m}$ syvyyden tuloksia. Koska tämä syvyys on nurmikasvien pääasiallisen juuristovyöhykkeen alapuolella (Salonen, 1949), voidaan vesinäytteistä löytyneen typen tulkita kuvaavan typen huuhtoutumisriskiä. Lannoitetyppenä käytettiin typpi-15rikastettua ammoniumnitraattia, ja vesinäytteistä määritettiin typpikonsentraatiot sekä niiden lannoitetypen osuus $\left({ }^{15} \mathrm{~N} /{ }^{14} \mathrm{~N}\right.$-isotooppikoostumus) aikasarjana. Näiden tietojen avulla on mahdollista määrittää lannoitetypen osuus kokonaistypestä ja arvioida huuhtoumariskiä mutta ei absoluutista typen huuhtouman määrää.

\section{Aineisto ja menetelmät}

Tutkimus suoritettiin MTT:n Maaningan tutkimusasemalla, Pohjois-Savossa. Tutkimuksessa käytettiin 6.4 hehtaarin kivennäismaapeltoa (Taulukko 1), jolle kylvettiin kesällä 2009 ruokohelpi (lajike Palaton). Ruokohelpiviljelmää aloitettaessa rajattiin tutkimuspellolta kolme $10 \mathrm{~m} * 20 \mathrm{~m}$ koealaa intensiivisiä mittauksia varten.

Timotei-nurminata-sekoitus [lajikkeet Tuure (timotei) ja Ilmarinen (nurminata)] valittiin ruokohelven verrokkikasviksi, koska ne ovat alueella paljon viljeltyjä nurmikasveja. Tutkimuspellon sijainnin valintaan vaikutti merkittävästi MTT Maaningalla sijaitseva lysimetrikenttä (Saarijärvi ym., 2007), jonka avulla on tarkoitus määrittää myöhemmin tutkimuspellon kokonaistyppihuuhtouma

Taulukossa 1 esitetään pintamaan ja huuhtoutumisvyöhykkeen ominaisuuksia, koska työssä keskityttiin 0,8 m syvyyteen. Taulukon 1 maaperäanalyysit tehtiin MTT Jokioisissa kesällä 2011. noudattaen Vuorinen \& Mäkitien (1955) ja Elosen (1971) kuvaamia menetelmiä. Taulukossa esitetään tulokset koealakohtaisesti, sillä pitkästä peltohistoriasta huolimatta tuloksissa nähtiin suurta vaihtelua erityisesti syvemmällä maassa (ks. taulukko 2). 
Taulukko 1. Tutkimuspellon maaperän ominaisuuksia koealoittain.

\begin{tabular}{|c|c|c|c|c|c|c|}
\hline & \multicolumn{3}{|c|}{$0-28 \mathrm{~cm}$} & \multicolumn{3}{|c|}{$78-93 \mathrm{~cm}$} \\
\hline & Koeala 1 & Koeala 2 & Koeala 3 & Koeala 1 & Koeala 2 & Koeala 3 \\
\hline Ca $\left(\mathrm{mg} \mathrm{l}^{-1}\right.$ maata $)$ & 1215,3 & 1354,3 & 1187,0 & 910,0 & 1132,0 & 1370,0 \\
\hline K (mg l ${ }^{-1}$ maata $)$ & 117,6 & 111,7 & 91,7 & 84,0 & 108,4 & 118,9 \\
\hline$M g\left(\mathrm{mg} \mathrm{l}^{-1}\right.$ maata $)$ & 180,6 & 195,0 & 141,7 & 271,7 & 522,3 & 597,6 \\
\hline$P\left(\mathrm{mg} \mathrm{l}^{-1}\right.$ maata $)$ & 5,0 & 4,5 & 6,1 & 1,4 & 0,9 & 1,2 \\
\hline $\mathrm{C}(\%)$ & 2,4 & 3,1 & 3,4 & 0,2 & 0,2 & 0,2 \\
\hline pH $\left(\mathrm{H}_{2} \mathrm{O} 1: 2,5\right)$ & 5,8 & 5,7 & 5,6 & 6,4 & 6,8 & 6,6 \\
\hline \multicolumn{7}{|c|}{ Mekaaninen maalaji } \\
\hline Sa & 22,1 & 31,8 & 21,8 & 13,9 & 31,2 & 57,2 \\
\hline Hs & 44,0 & 30,9 & 24,4 & 27,0 & 52,1 & 37,2 \\
\hline HHt & 19,6 & 16,5 & 23,9 & 41,4 & 15,1 & 4,7 \\
\hline KHt & 9,7 & 15,8 & 24,9 & 16,5 & 1,1 & 0,6 \\
\hline $\mathbf{H k}$ & 4,7 & 5,0 & 5,2 & 1,4 & 0,7 & 0,4 \\
\hline
\end{tabular}

\section{Koejärjestely, typpi-15-lannoituskoe ja näytteiden analyysit}

Koepellolle rajatut kolme $200 \mathrm{~m}^{2}$ koealaa jaettiin kolmeen osaan koostuen ruokohelpiviljelmästä, paljaasta maasta sekä nurmiviljelmästä (ks. kuva 1). Loppuvuodesta 2009 asennettiin näille alueille (ruokohelpi- ja nurmiviljelmät) keraamiset imuputket vesinäytteiden ottoa varten. Putkien kärkiosa on keraaminen ja siten vettä läpäisevä; kärkiosa upotettiin maahan $0,8 \mathrm{~m}$ syvyyteen poraamalla maahan putken halkaisijan kokoinen reikä (putken $\mathrm{h}=71 \mathrm{~cm}, \mathrm{~d}=2 \mathrm{~cm}$ ja $\mathrm{V}=$ $100 \mathrm{ml}$ ). Näytteenotot suoritettiin imemällä näytteenottoputkeen alipaine vuorokautta ennen näytteenottoa (käsipumpulla $\sim 0.8$ bar alipaine). Keraamisen kärjen ympäröimä maavesi syrjäyttää putken alipaineen kertymällä putkeen, josta vesinäyte imettiin imuputkeen sijoitetun silikoniletkun kautta steriiliin astiaan. Vastaavasti, jos maavettä ei ole keraamisen osan ympärillä, syrjäyttää ko. syvyyden ilma alipaineen, jolloin vesinäytettä ei saada. Näin ollen vesinäytteiden otto vaatii maalta riittävän vesipitoisuuden. Keraamisista imuputkista saadut vesinäytteet yhdistettiin koealakohtaisesti, jolloin näyte koostui neljän vesikeräimen vedestä. ${ }^{15} \mathrm{~N}$-lannoite levitettiin mahdollisimman homogeenisesti määräaloille. Tästä syystä lannoite levitettiin vesiliuoksessa. Lannoitetyppiliuokset valmistettiin vastaamaan $0.1 \mathrm{~mm}$ sadetta. Typpiliuos levitettiin torjunta-aineiden levitykseen kehitetyllä työnnettävällä laitteistolla (työleveys $1.5 \mathrm{~m}$ ) avulla (Esala \& Kakkonen, 1998).

Lannoitetypessä (ammonium-nitraatti; ${ }^{15} \mathrm{NH}_{4}{ }^{15} \mathrm{NO}_{3}$ ) oli kumpikin typpi leimattu ${ }^{15} \mathrm{~N}$ :1lä (10 AT$\%$, Campro Scientific, Cat. No. CS01-185-138). Kummallekin kasville annettiin alue- ja kasvikohtaisten suositusten mukaiset lannoitemäärät (ruokohelpi $75 \mathrm{~kg} \mathrm{~N}$ ha-1, nurmi $100 \mathrm{~kg} \mathrm{~N}$ ha-1). Lannoituskoe ${ }^{15} \mathrm{~N}$ :1lä (rikastuskoe) aloitettiin 31.5.2011 - neljä päivää myöhemmin kuin määräalojen "rikastamattomat" alueet, jonne lannoitus tehtiin koneellisesti.

Nurmen ensimmäinen niitto suoritettiin 22.6.2011. Noin kahden viikon kuluttua (7.7.2011) annettiin nurmelle uudestaan rikastuslannoitus (100 kg N ha-1) yllä kuvatulla menetelmällä. Toinen niitto suoritettiin 5.9.2011. Tuotettaessa ruokohelpeä polttoon, se jätetään kuivumaan pellolle talven. Niitto tehtiin vasta keväällä 8.5.2012. Rikastettua lannoitetyppeä seurattiin 31.5.2012 asti.

Kerätyistä vesinäytteistä määritettiin epäorgaaniset typen $\mathrm{t}\left(\mathrm{NH}_{4}\right.$ ja $\mathrm{NO}_{3}$; tässä esitetään vain $\mathrm{NO}_{3}$-tulokset) konsentraatiot ionikromatografilla (DX 120, Dionex Corporation, USA) ja spektrometrilla (Ultrospec 3000 pro, Biochrom, UK). Lisäksi vesinäytteistä määritettiin $\mathrm{NH}_{4}-\mathrm{N}: \mathrm{n}$ ja $\mathrm{NO}_{3}-\mathrm{N}: \mathrm{n}$ isotooppikoostumukset [Elemental Analyzer Isotope Ratio Mass Spectrometer (EA-IRMS); Thermo Scientific]. Vesinäytteiden epäorgaaniset typpifraktiot erotettiin näytevedestä ns. mikrodiffuusiomenetelmällä, jossa epäorgaaninen typpi kerättiin happoon suolaksi (kiinteä aine) (modifioitu menetelmästä Stark \& Hart, 1996). jonka isotooppikoostumus analysoitiin EA-IRMS:1la. Näytteiden esikäsittely ja laboratoriotyöt sekä analyysit suoritettiin Itä-Suomen Yliopistossa, Kuopion kampuksella. 


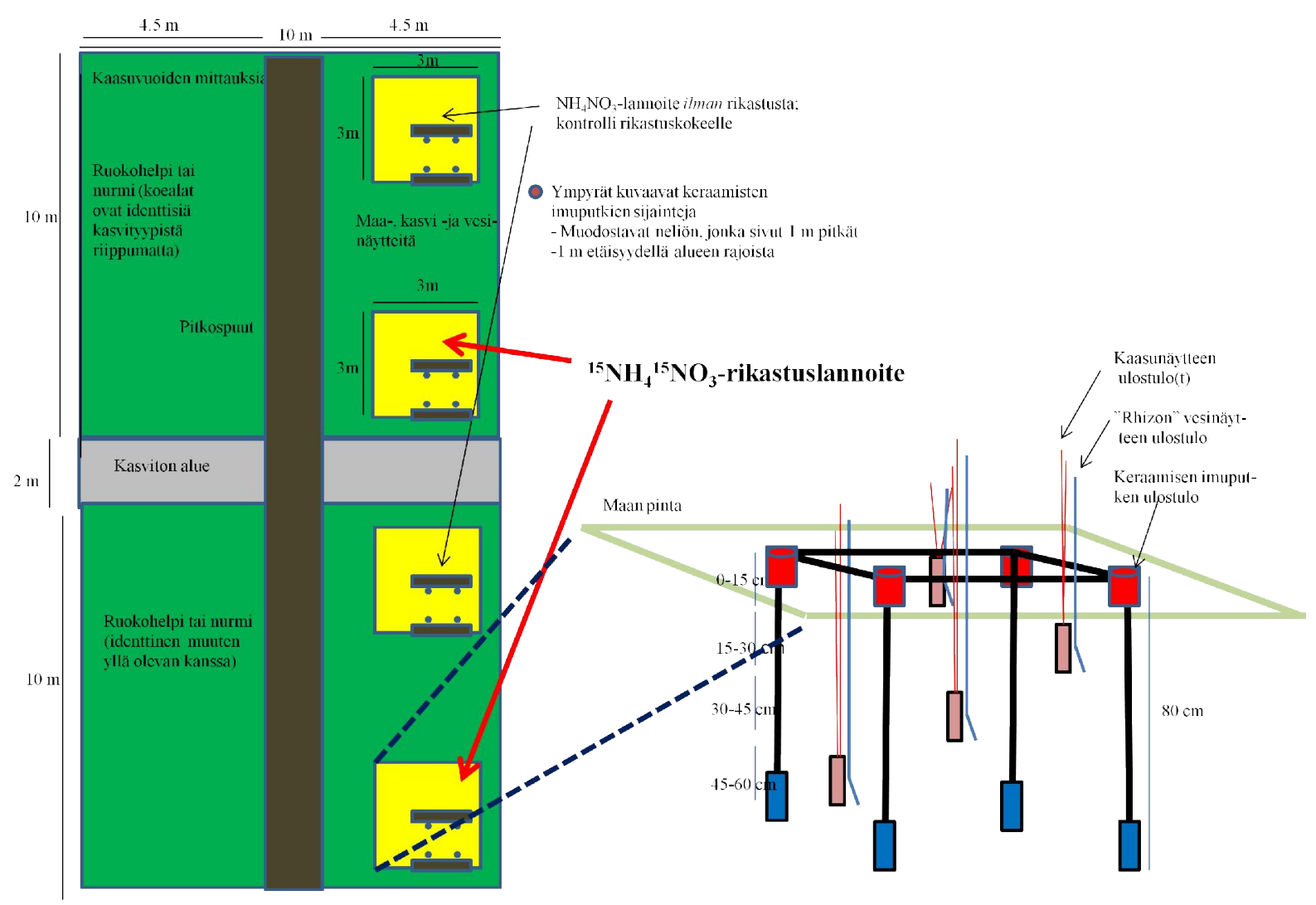

Kuva 1. Koejärjestely ja maahan asennettujen vesikeräinten kaaviokuva. Siniset suorakaiteet kuvastavat imuputkien keraamista osaa. Vastaavia koealoja oli tutkimuspellolla kolme kappaletta.

\section{Tulokset ja tulosten tarkastelu}

Ensimmäiset imukeräinvesinäytteet $(0,8 \mathrm{~m})$ otettiin kolme päivää ${ }^{15} \mathrm{~N}$-lannoituksen jälkeen. Tällöin lannoitetypen nitraatin osuus kokonaisnitraattihuuhtoumasta oli 0,09 $\pm 0,03 \%$ (keskiarvo \pm SE) (ks. kuva 2 ja kuva 2B). Ruokohelven lannoitetyppiosuus pysytteli alle prosentin osuudessa 6.7.2011 asti. Kesäkuun 20. päivä lannoitetypen osuus nousi korkeimmilleen, 1,62 $\pm 1,1$ \%:iin. Lannoitetypenosuus laski tämän jälkeen tasaisesti 14.9.2011 asti neljännesprosenttiin. Loppuvuoden lannoitetypen-osuus kasvoi tasaisesti ja jopa kolminkertaistui, mutta ollen kuitenkin 22.12.2011 vielä alle prosentin nitraattihuuhtouman kokonaismäärästä. Toukokuun 2012 alussa huuhtoutuvan lannoitetypen osuus oli $1,90 \pm 0,8 \%$, ollen näin korkeimmillaan vuoden mittaisessa seurantajaksossa. Vuosi lannoitetypen lisäyksestä (31.5.2012) lannoiteperäinen nitraatti oli $1.5 \%$ kokonaisnitraattihuuhtoumasta.

Nurmen ensimmäisen lannoituksen jälkeen nitraatin huuhtouma oli samankaltainen ruokohelven huuhtouman kanssa vaikka nurmi sai $25 \%$ suuremman lannoitemäärään. Kolme päivää lannoituksesta lannoiteperäinen nitraatti oli $0,36 \pm 0,03 \%$ kokonaisnitraattihuuhtoutumasta (ks. kuva 2). Lannoiteperäisen $\mathrm{NO}_{3}$-N:nosuus laski tasaisesti kesäkuun loppua kohden. Toinen lannoitus, typpimäärältään ensimmäistä vastaava, suoritettiin 7.7.2011. Kahdeksan päivän kuluttua lannoituksesta todettiin lannoitetyppimaksimi $(34,5 \pm 19,2 \%)$ kokonaisnitraattihuuhtoumasta. Lannoitenitraatin osuus laski heinäkuun huippuarvosta aina 14.9.2011 asti, jolloin ko. osuus oli enää 2,5\%. Lannoitetypen osuus huuhtoumassa aleni näin yli $90 \%$ kahdessa kuukaudessa. Tämän jälkeen huuhtoutuvan lannoite- $\mathrm{NO}_{3}-\mathrm{N}$ :n osuus kaksinkertaistui 12.10.2011 mennessä. Loppuvuotta kohden lannoiteperäisen $\mathrm{NO}_{3}-\mathrm{N}: n$ määrä laski hieman. Toukokuun 2012 alussa lannoite- $\mathrm{NO}_{3}-\mathrm{N}: n \%$ osuus oli noin $2,5 \%$. 


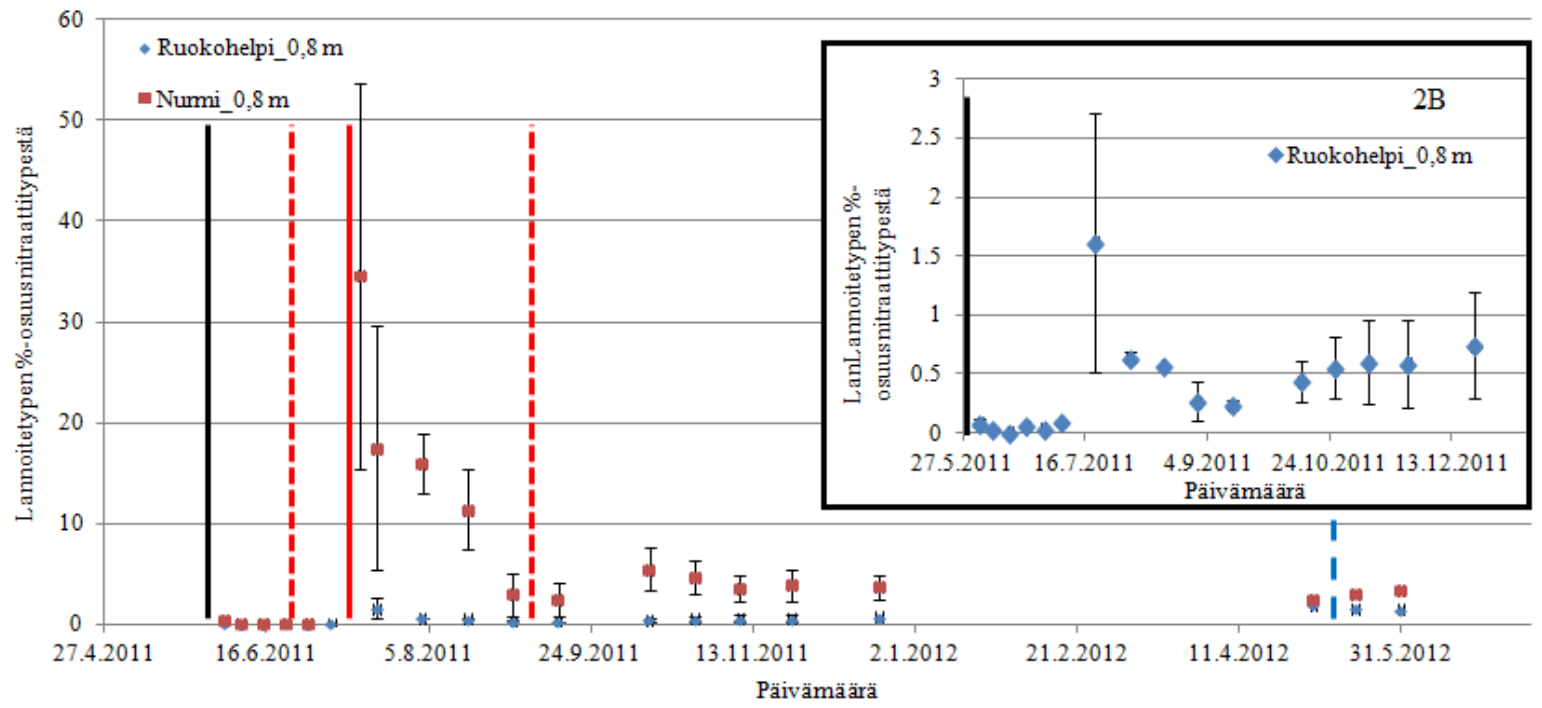

Kuva 2: Lannoitetypen \% -osuus $0,8 \mathrm{~m}$ syvyydeltä keraamisista imuputkista otetuissa vesinäytteissä (keskiarvo \pm keskiarvon keskivirhe). Musta viiva kuvastaa ensimmäisen lannoituksen ajankohtaa kummallekin kasville, punainen viiva nurmen toista lannoitusta, punaiset katkoviivat nurmen niittohetkiä ja sininen katkoviiva ruokohelven niittoa. Kuva 2B: Tarkennus ruokohelven lannoitetypen \% -osuuteen $\mathrm{NO}_{3}-\mathrm{N}$ :sta.

Ruokohelvellä typpilannoitus ei lisännyt merkittävästi nitraattitypen huuhtoutumista $0,8 \mathrm{~m}$ syvyyteen. Nitraattityppikonsentraatio oli keskimäärin $7 \mathrm{mg} \mathrm{NO}{ }_{3}-\mathrm{N} \mathrm{l}^{-1}$ aikavälillä 19.5. - 22.6.2011 (ks. kuva 3). Kesäkuun lopussa $\mathrm{NO}_{3}-\mathrm{N}$ saavutti korkeimman pitoisuuden, jonka jälkeen $\mathrm{NO}_{3}-\mathrm{N}-$ pitoisuus alkoi laskea tasaisesti loppuvuotta kohden. Alimmillaan $\mathrm{NO}_{3}-\mathrm{N}$ pitoisuus oli 26.10.2011 $\left(1,8 \pm 0,2 \mathrm{mg} \mathrm{l}^{-1}\right)$. Toukokuussa $2012 \mathrm{NO}_{3}-\mathrm{N}$ - pitoisuus vaihteli välillä $0,1-1,3 \mathrm{mg} \mathrm{NO}_{3}-\mathrm{N}^{-1}$.

Nurmella nitraattitypen konsentraatio $0,8 \mathrm{~m}$ syvyydellä oli keskimäärin $8 \mathrm{mg} \mathrm{NO} \mathrm{NO}_{3}-\mathrm{N} \mathrm{l}^{-1}$ (aikavälillä 19.5. - 14.9.2011, ks. taulukko 2). Nurmella ensimmäinen ja toinen typpilannoitus ei aiheuttanut merkittävää nousua nitraattipitoisuuksissa $0,8 \mathrm{~m}$ syvyydestä Lokakuussa $\mathrm{NO}_{3}-\mathrm{N}-$ konsentraatio puolittui aiemmasta $8 \mathrm{mg} \mathrm{NO}_{3}-\mathrm{N} \mathrm{l}^{-1}$ pitoisuudesta.. Toukokuussa $2012 \mathrm{NO}_{3}$-N-pitoisuus nousi arvosta $0,40 \pm 0,2 \mathrm{mg} \mathrm{l}^{-1}$ arvoon $10,3 \pm 4,3 \mathrm{mg} \mathrm{l}^{-1}$.

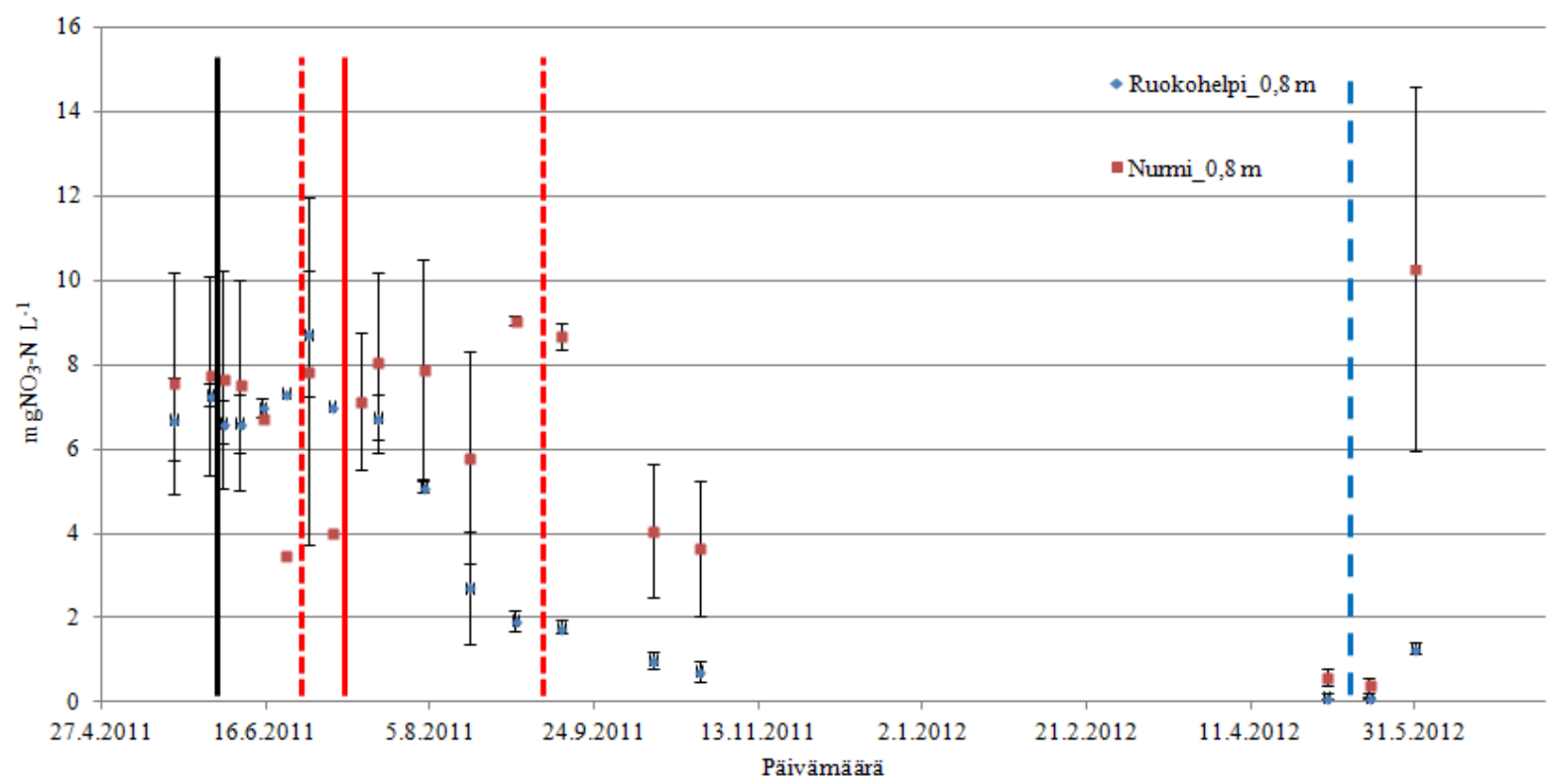

Kuva 3. Nitraattityppikonsentraatiot $0,8 \mathrm{~m}$ syvyydellä keraamisista imuputkista otetuissa vesinäytteissä (keskiarvo \pm keskiarvon keskivirhe). Musta viiva kuvastaa ensimmäisen lannoituksen ajankohtaa kummallekin kasville, punainen viiva nurmen toista lannoitusta, punaiset katkoviivat nurmen niittohetkiä ja sininen katkoviiva ruokohelven niittoa. 
Ruokohelven nitraattityppipitoisuudet $0,8 \mathrm{~m}$ syvyydellä olivat yleisesti ottaen hieman matalammat kuin nurmen. Kummallakin kasvilla $\mathrm{NO}_{3}-\mathrm{N}$ pysyi alkukesästä elokuun alkuun noin $7 \mathrm{mg}$ $1^{-1}$ - pitoisuudessa, jonka jälkeen pitoisuudet vähintään puolittuivat kummallakin kasvilla. Ruokohelven nitraattihuuhtouma Maaningan ruokohelpikokeessa oli hieman korkeampi kuin mitä Curley ym. 2009) saivat Irlannissa norsuheinäviljelmälle (Miscanthus x gigantis) (lannoitustasot $60 \mathrm{ja}$ $120 \mathrm{~kg} \mathrm{~N} \mathrm{ha}^{-1}$ ). Saarijärvi ym. (2004) raportoivat Maaningalla lysimetrikentällä viljellyn nurmen (timotei-nurminata; $220 \mathrm{~kg} \mathrm{~N} \mathrm{ha}^{-1}$ ) huuhtoumasta $0,5-4,5 \mathrm{mg} \mathrm{NO}_{3}-\mathrm{N} \mathrm{l}^{-1}$, saaden tätä työtä hieman alhaisempia nitraattipitoisuuksia. Kevään 2012 nurmella kohonnut $\mathrm{NO}_{3}$-N-pitoisuus viittaa keväthuuhtoumaan (mm. Cameron ym., 2013)

Taulukko 2. Kolmen näytteenottohetken tuloksia nitraattitypen kokonaispitoisuuksille ja lannoiteperäisen nitraatin osuuksille nitraatin kokonaismäärässä $0,8 \mathrm{~m}$ syvyydessä kolmelta koealalta.

\begin{tabular}{|c|c|c|c|c|c|c|c|}
\hline & & \multicolumn{3}{|c|}{ Ruokohelpi } & \multicolumn{3}{|c|}{ Nurmi } \\
\hline Päivämäärä & Parametri & $\begin{array}{c}\text { Koeala } \\
1\end{array}$ & $\begin{array}{c}\text { Koeala } \\
2\end{array}$ & $\begin{array}{c}\text { Koeala } \\
3\end{array}$ & $\begin{array}{c}\text { Koeala } \\
1\end{array}$ & $\begin{array}{c}\text { Koeala } \\
2\end{array}$ & $\begin{array}{c}\text { Koeala } \\
3\end{array}$ \\
\hline \multirow[b]{2}{*}{ 3.6.2011 } & Pitoisuus ( $\mathrm{mg} \mathrm{NO}_{3}-\mathrm{N}^{-1}$ ) & 6,6 & 7,5 & 5,8 & 2,5 & 10,5 & 9,9 \\
\hline & $\begin{array}{c}\text { Lannoitetypen \% - } \\
\text { osuus nitraattitypestä }\end{array}$ & 0,2 & 0,0 & 0,1 & 1,0 & 0,1 & 0,0 \\
\hline \multirow{2}{*}{ 20.7.2011 } & Pitoisuus ( $\mathrm{mg} \mathrm{NO}_{3}-\mathrm{N}^{-1}$ ) & 6,2 & 7,3 & - & 4,0 & 11,2 & 9,0 \\
\hline & $\begin{array}{c}\text { Lannoitetypen \% - } \\
\text { osuus nitraattitypestä }\end{array}$ & 0,5 & 2,7 & - & 40,9 & 11,5 & 0,1 \\
\hline \multirow[b]{2}{*}{26.10 .2011} & Pitoisuus ( $\mathrm{mg} \mathrm{NO}_{3}-\mathrm{N}^{-1}$ ) & 1,2 & 0,5 & 0,5 & 0,5 & 5,7 & 4,7 \\
\hline & $\begin{array}{c}\text { Lannoitetypen \% - } \\
\text { osuus nitraattitypestä }\end{array}$ & 1,1 & 0,3 & 0,2 & 6,7 & 5,9 & 1,3 \\
\hline
\end{tabular}

Tuloksissa esiintyi voimakasta hajontaa erityisesti nurmella, johtuen todennäköisesti maaperän ominaisuuksista (ks. taulukot 1 ja 2). Koeala 1 oli näytteenottosyvyydeltä $(0,8 \mathrm{~m})$ pääosin hienoa hietaa ja hiesua, kun taas koeala 2 oli hiesua ja koeala 3 savea. Ruokohelvellä $\mathrm{NO}_{3}$-N-pitoisuudet olivat koealojen kesken samankaltaisia näytteenottohetkestä riippumatta, kun taas nurmella koeala 1 poikkesi systemaattisesti koealoista 2 ja 3 antaen keskimäärin $20 \%$ pienempiä $\mathrm{NO}_{3}$-N-pitoisuuksia (taulukko 2). Ero näkyi myös lannoitetypenosuudessa kokonaisnitraatista. Konsentraatiotuloksista poiketen lannoitenitraatin osuus käyttäytyi päinvastoin: nurmella lannoitetyppeä huuhtoutui koealalla 1 enemmän alempiin makerroksiin kuin koealoilla 2 ja 3. Todennäköisesti syvempien maakerrosten erot selittävät poikkeavuudet sillä koealojen pintakerrokset olivat muita kerroksia homogeenisemmat.

\section{Johtopäätökset}

Erilaisista lannoituskäytännöistä huolimatta maaperän huokosveden nitraattipitoisuuksissa $(0,8$ m) ei tavattu merkittäviä eroja ruokohelven ja nurmen kesken. Kummallakin kasvilla ensimmäisestä typpilannoituksesta huuhtoutui vain alle prosentti nitraattina. Nurmen toinen lannoitus lisäsi lannoitetypestä peräisin olevan nitraatin huuhtoutumista Sateella (määrä ja/tai ajoitus) oli todennäköisesti merkittävä osuus lisälannoituksen aiheuttamassa huuhtoutumisessa. Nurmen toistuvan lannoituksen aiheuttamasta huuhtoutumisriskistä olisi saatava tarkempaa tietoa. Myös maaperäkerrosten ominaisuudet vaikuttavat huuhtoutuvan nitraatin määrään.

\section{Kirjallisuus}

Cameron, K. C., Di, H. J. \& Moir, J. L. 2013. Nitrogen losses from the soil/plant system: a review. Annals of Applied Biology, no. 162, ss. 145 - 173.

Curley, E. M., O'Flynn, M. G. \& McDonnell, K- P. 2009. Nitrate leaching losses from Miscanthus $\mathrm{x}$ giganteus impact on groundwater quality. Journal of Agronomy, no. 8, s. $107-112$.

Elonen, P. 1971. Particle-size analysis of soil. Acta Agralia Fennica 122: 1-122. 
Esala, M. \& Kakkonen, K. 1998. A light-weight apparatus for applying $15 \mathrm{~N}$-labelled fertilizer to field micro-plots (Research Note). Journal of Agricultural Engineering Research, no. 69, s. 95 - 97.

Hyvönen, N. P., Huttunen, J. T., Shurpali, N. J., Tavi, N. M., Repo, M.E. \& Martikainen, P. J. 2009. Fluxes of nitrous oxide and methane on an abandoned peat extraction site: Effect of reed canary grass cultivation. Bioresource Technology, no. 100, s. $4723-4730$.

Mavi. 2013. Maaseutuvirasto. http://www.mavi.fi/fi/oppaat-ja-lomakkeet/viljelija/Documents/ Opas\%20ymp\%C3\%A4rist\%C3\%B6tuen\%20ehtojen\%20mukaiseen\%20lannoitukseen\%2020072013.pdf. Viitattu 23.12.2013.

Partala, A. \& Turtola, E. 2000. Biomassanurmi estää tehokkaasti typen huuhtoutumista. Koetoiminta ja käytäntö, no. 57, s. 6 .

Richards, J.H. 1993. Physiology of plants recovering from defoliation. Proceedings of the XVII International Grassland Congress, 8 - 21 Feb. 1993, Palmerston North, New Zealand. s. 85 - 94.

Saarijärvi, K., Virkajärvi, P., Heinonen-Tanski, H. \& Taipalinen, I. 2004. N and P leaching and microbial contamination from intensively managed pasture and cut sward on sandy soil in Finland. Agriculture, Ecosystems and Environment, no. 104, s. 621 - 630.

Saarijärvi, K. Virkajärvi, P. \& Heinonen-Tanski, H. 2007. Nitrogen leaching and herbage production on intensively managed grass and grass-clover pastures on sandy soil in Finland. Euroapean Journal of Soil Science, no. 58, s.1382 - 1392.

Salo, T., Turtola, E., Virkajärvi, P., Saarijärvi, K., Kuisma, P., Tuomisto, J., Muurinen, S. \& Turakainen, M. 2013. Nitrogen fertilizer rates, $\mathrm{N}$ balances, and related risk of $\mathrm{N}$ leaching in Finnish agriculture. MTT Raportti 102, s. 37.

Salonen, M. 1949. Tutkimuksia viljelykasvien juurten sijainnista Suomen maalajeissa. Acta Agralia Fennica, no. 70, s. 83.

Shurpali, N. J., Hyvönen, P. J., Huttunen, J. T., Clement, R. J., Reichstein, M., Nykänen, H., Biasi, C. \& Martikainen, P. J. 2009. Cultivation of a perennial grass for bioenergy on a boreal organic soil - carbon sink or source? Global Change Biology Bioenergy, no. 1, s. 35 - 50.

Stark, J. \& Hart, S. 1996 Diffusion technique for preparing salt solutions, Kjehldahl digests persulphate digests for nitrogen 15-analysis. Soil Science Society of America, no. 60, s. 1846 - 1855.

TIKE. 2012. Maa- ja metsätalousministeriön tietopalvelukeskus. Maataloustilastollinen vuosikirja 2012, s. 269.

Valpasvuo-Jaatinen, P., Rekolainen, S. \& Latostenmaa, H. 1997. Finnish agriculture and its sustainability: envirnmental aspects. Ambio no. 26, s. 448 - 455.

Vuorinen, J. \& Mäkitie, O. 1955. The method of soil testing in use in Finland. Agrogeological Publications no. 63, s. 44.

Whitehead, D.C. 1995. Grassland nitrogen. CAB international. 397 p. 